International Review of Research in Open and Distributed Learning Volume 22, Number 1

February - 2021

\title{
Comparative Analysis of Operational Structures in Single- and Dual-Mode Distance Learning Institutions in Nigeria
}

Taiwo Isaac Olatunji1 and Tajudeen Adewumi Adebisi, PhD2

${ }^{1}$ Department of Philosophy, Sociology, Pedagogy and Applied Psychology, University of Padua, ${ }^{2}$ Department of Adult Education and Lifelong Learning, Obafemi Awolowo University, lle-lfe

\begin{abstract}
This study examined the similarities and differences in the processes and facilities for distance education at National Open University of Nigeria (NOUN), a single-mode distance learning institution, and Obafemi Awolowo University (OAU), Ile-Ife, a dual-mode distance learning institution. The study adopted a case study research design, with a population of administrators/facilitators and distance learning students at both NOUN and OAU. The sample for the study consisted of 38 key informants (30 administrators/facilitators and 8 students) selected using a purposive sampling technique. All the administrators/facilitators responded to a key informant questionnaire; 8 of the administrators/facilitators and all 8 students were also interviewed. The 16 interviewees were selected based on gender, institution, educational role, and mode of distance learning. The collected data were analysed using tabular juxtaposition and phenomenological analysis techniques. Results showed that similarities in the operational structures at NOUN and OAU included the use of blended learning approaches. Differences in operations included compulsory tutorial attendance at OAU and the deployment of part-time and quasi part-time facilitators at NOUN and OAU, respectively. The study recommended an increase in the use of information and communications technology (ICT).
\end{abstract}

Keywords: operational structures, single-mode, dual-mode, distance learning institutions, Nigeria 


\section{Introduction}

Distance education has been defined as formal learning in which the learner and the facilitator are separated in time and space (Bušelić, 2012). It encompasses part-time courses/studies, open and distance learning, and online education, and especially for post-secondary education, distance learning and digital learning/education. In the Nigerian education system, distance education was conceptualised as "allinclusive contact, no contact and part-time education ... the mode of teaching in which learners [are] removed in time and space from the teacher" (Federal Republic of Nigeria [FRN], 2004, p. 38). Nigeria's national policy on education (FRN, 2004, 2013) acknowledged the need for a variety of media and technologies. Operational structures referred to the institution's defined chains of activities and processes as these relate to the conduct of admission, course registration, instructional delivery, staffing, examinations, and certification towards achieving the learner's needs and institution's goals. Nigeria is the most populous and the largest economy in Africa (Akinwale \& Onwuamaeze, 2020; Naido, 2020; Terwase, Abdul-Talib \& Zengeni, 2014). The country's vast geographical, socio-cultural, and ethnolinguistic diversities make higher education through distance learning desirable and imperative. Distance education creates an opportunity for lifelong learning, life-wide education, mass and media education, self-directed learning, personalised learning, and part-time studies. Distance education programmes also allow higher institutions to optimally utilise their facilities.

The National Open University of Nigeria (NOUN) is the only dedicated distance learning university in the country (Okonkwo, 2012) while OAU, Ile-Ife, is one of the institutions that provides university education through traditional and distance education modes (Oyeleke \& Apena, 2018). The motto of NOUN is Work \& Learn. NOUN was founded in 1983 but did not become fully functional until 2002. OAU, Ile-Ife, was founded in 1962 and its motto is For Learning and Culture. This comprehensive public institution has aspired to be the technological flagship of the West African sub-region in teaching, research, and community service. Today, OAU is a leader in ICT at the university level in Nigeria, and one of the few accredited dual-mode institutions offering higher education through distance learning in Nigeria (Agyeman, 2007; Onwe, 2013). It does this through its Centre for Distance Learning (CDL) and the Institute of Education (IED). In 2014, the CDL commenced coordinating the university's online degree programmes in various fields of study while the IED coordinated part-time degree programmes in education courses. Nigeria's federal government own and finance NOUN and OAU.

Despite the enthusiasm for distance education among Nigeria's tertiary institutions, some uncertainties and concerns remain about the type, scope, and nature of distance education provision in Nigeria. There are concerns about infrastructural inadequacy, organisational and operational modes, among others (Biao, 2012; Ikegulu \& Oranusi, 2014; Oyeleke \& Apena, 2018). It may be that many prospective distance learners do not have adequate information or sufficient understanding of the operational modes of varied distance learning institutions with regards to their instructional delivery methods, facilities, as well as patterns of learners' and facilitators' activities. It appears these misconceptions make some people assume that distance learning is a second-best option (Gaskel \& Mills, 2015) even though studies such as Tucker's (2001) have proved that distance education could be as effective as traditional education.

Obioha and Ndidi (2011) and Ezekoka (2015) investigated some aspects of the administrative and operational structures of NOUN. Meanwhile, extant literature has shown little evidence of works on 
distance education that juxtapose dual-mode and single-mode institutions using a mixed methods approach. Many previous studies have focused on comparing trends and practices in different countries (Adanir et al., 2020; Srivastava, 2002; Zormanová, 2016) and comparing distance education and conventional education (Abdulsalam et al., 2017; Adeleke \& Adesina, 2018; Ahn \& McEachin, 2017; Anderle, 2018; Anderson \& Cuttler, 2020; Duffy et al., 2002; López Soblechero et al., 2014; Olakulehin \& Panda, 2011; Paul \& Jefferson, 2019). A recent study compared single- and dual-mode institutions in Pakistan, and analysed how distance learners' assignments were assessed (Akter \& Ali, 2016). Institutions' operational structures need to be examined and understood to empirically show how this aspect has contributed to the development of modern distance education in Nigeria. Importantly, understanding the operational structures in single- and dual-mode distance learning institutions would help to better position distance education in the society that is sceptical of it; hence, this study. The study answered the following question: what are the similarities and differences in the processes and facilities for distance learning in single- and dual-mode distance learning institutions in Nigeria, specifically at NOUN and OAU? The objectives of the study were to identify, describe, and compare the operational structures (i.e., processes and facilities) at NOUN and OAU.

\section{Overview of Distance Learning in Nigeria}

Education policymakers in Nigeria envisaged the need for a mode of education that would increase access and opportunities to formal learning for personal development and the ultimate betterment of society. Such provision was based on the principles of equity, egalitarianism, as well as the need for lifelong learning for Nigerian adult citizens. The National Policy on Education (FRN, 2013, Section 6) provided for open and distance education and emphasised that this kind of education delivery system be encouraged and promoted at different levels and for varied purposes nationwide. According to the FRN (2013, Section 6, paragraph 115), the goals of open and distance education in Nigeria, among others, are access to quality education, equity in educational opportunities, and lifelong learning opportunities. In Nigeria, distance education has been expected to include contact, no contact, part-time, and flexible education, all through deploying a variety of media and technologies (FRN, 2004, 2013).

Even so, necessary and supportive infrastructures such as the regular supply of electricity and efficient telecommunication network have been lacking. E-learning and online education in Nigeria is still a dream because of poor ICT infrastructure and other socio-economic reasons (Agyeman, 2007; Ajadi et al., 2008; Akande \& Sofowora, 2011; Commonwealth of Learning [COL], 2001). Meanwhile, Ajadi et al. (2008, p. 1) advised that "the rapid expansion of ICTs in Nigeria offers an opportunity to consider its use in the promotion" of distance education. The Federal Ministry of Education (2000) admitted that following the early start in distance education in the 1950s, there has been a relapse since the 1960s. More than a decade and a half ago, the country began to revamp its distance education potential by developing a 10-year plan of action for distance education in Nigeria, designed to span the years from 2001 to 2010.

Agyeman (2007, citing Nom, 2006) described how each of the NOUN study centres was furnished with a computer laboratory, designed as a cyber cafe with a minimum of 25 computers in a local area network configuration. Temitayo (2012) noted that NOUN also had some special study centres in order to cater to 
specialised groups such as prison inmates and armed forces personnel. Agyeman (2007) added that the Government of Nigeria had also ceded to NOUN the educational unit of the Nigeria Television Authority in Tejuosho, Lagos, so as to enable NOUN to televise some of its courses, and that NOUN already used videoconferencing for some course delivery. Ajadi et al. (2008) further reported that NOUN established a radio station in Lagos as one strategy for facilitating its programmes. Ajadi et al., however, recommended that before introducing an advanced ICT at NOUN, research should be conducted on learner's access, cost, and other related and essential parameters. Meanwhile, according to Onwe (2013), NOUN's instructional delivery system was still restricted to the use of printed materials and CD-ROMs with plans to include (a) audiotapes, (b) videotapes, (c) radio and television broadcasts, and (d) computer-mediated learning. According to Ezekoka (2015), NOUN students preferred blended learning to the practice of only face-toface instruction. However, the constraints to the use of blended learning at NOUN included: (a) students at times felt lonely and isolated when using blended learning, (b) technophobia, (c) students' lack of computer operating skills, (d) high cost of ICT, (e) poor Internet connectivity, and (f) the fact that blended learning required students to devote more time to their studies.

OAU has practiced an integrated, dual-mode model of distance education. OAU's CDL, responsible for facilitating modern distance education, is located in Moro, about seven kilometres away from the main campus in Ile-Ife. The CDL has been furnished with technical infrastructure to cater to the institution's online programmes. OAU is an example of institutions that have made notable efforts in reducing reliance on national infrastructure. Agyeman's (2007) survey recorded that:

The Obafemi Awolowo University (OAU) boasts of having the best-developed ICT system in the country with its VSAT access to the Internet and a campus-wide intranet. OAU has embarked on the progressive application of ICT to all its functions and services-academic, research, and administrative. The OAU has more than 6,000 users on more than 1,000 computers distributed in 15 computer laboratories across the campus. (p. 7)

OAU's online facility has been aligned with one of the objectives of Nigeria's federal government in its plan for distance education: the establishment of a robust ICT-driven delivery system (Association for the Development of Education in Africa, 2002 in Onwe, 2013). Apart from this, OAU has offered distance education through its IED, which coordinates part-time degree programmes in the Faculty of Education.

\section{Distinguishing Between Single- and Dual-Mode Institutions}

As Trindade et al. (2000) stated, the distinction between single- and dual-mode distance learning organisations is a classical one. The former applies to organisations where distance learning activities largely dominate, compared with face-to-face ones. As of 2001, the only example of dedicated distance education institution in Nigeria was the National Teachers' Institute, but it was not a university. However, since 2002, an open university experience has been available only through NOUN. Dual-mode institutions are described as conventional universities with units that organise and operate structured distance education programmes (COL, 2001). Examples of such units have been found in the University of Ibadan, the University of Lagos, the University of Abuja, and OAU. COL (2001) observed that in some institutions, 
such as the University of Ibadan, distance education practices were organised by a unit originally set up for adult education.

In a single-mode system, students work mostly by themselves outside the campus; their direct contact with the system occupies just a small fraction of their yearly workload. This is the usual organisational pattern of open universities, also known as dedicated distance learning universities. According to Trindade et al. (2000), when conventional universities decide to operate distance learning methods in some programmes in parallel with their conventional operation, this has constituted a dual-mode system. Trindade et al. affirmed that "this solution has been adopted by an increasing number of traditional universities as a means to provide education to students unable to follow courses regularly on campus, thereby expanding the social usefulness and the geographical radius of their influence" (pp. 4-5).

COL's (2001) report described three major kinds of institutional practice in Nigeria: (a) outreach as distance education, (b) dual-mode institutions, and (c) dedicated distance education institutions. The report admitted that the outreach centres practice did not fall into the ambit of distance education as it was outside international conceptualisation, and the centres were of low and uncoordinated quality. Consequently, the National Universities Commission (NUC) banned the outreach practice. Meanwhile, COL's report strongly emphasised the need to locate distance education units within dual-mode institutions. The report noted that this approach was believed to have physical, psychological, and administrative implications, as it addressed (a) the tendency for distance education to be regarded as a second-best option (which promotes a feeling of inadequacy); (b) the need to generate income for the mother institution for the management of the unit (which could lead to the sacrifice of quality at the altar of money); (c) the tendency for finances to be managed by the central institutional administration; and (d) the tendency for distance education units to rely heavily on course writers who are already employed as full-time lecturers. The approach was also viewed as being advantageous in the sense that it prevented brain drain from the Nigerian university system, allowed distance education programmes to work directly with content experts, and reduced cost.

\section{Conceptual Framework: Distance Education Models}

There have long been various groupings of models of distance education. This study hinged on Keegan's (1990, 1996) models of distance education. According to Keegan's typology of distance teaching systems, there are five models of distance education: (a) correspondence school model (Group 1), (b) distance teaching universities or open university model (Group 2), (c) independent study divisions of a conventional college or university (Group 3) integrated model, (d) consortium model (Group 4), and (e) Australian integrated mode or New England model (Group 5). Keegan categorised Groups 1 and 2 under autonomous distance teaching institutions and Groups 3, 4, and 5 under distance education departments of conventional institutions. The fundamental differences among the groupings is in the two categories (Keegan, 1996). The division between Group 2 and 2 "is based on complexity of didactic structure and level of provision" (Keegan, 1996, p. 131).

The correspondence school model relies heavily on the exchange of print materials between the institution and the students, especially at below university level. It appears that with the exponential increase in 
technological development and globalisation since the 1990's, this model has gradually faded. In fact, because of the use of "correspondence" in the Act that established NOUN, its graduates were not regarded as equal to graduates of conventional universities until the word was expunged in 2017 (Baiyewu, 2017). In the distance teaching universities or open university model provisions are usually at the tertiary level, although non-degree courses might be offered. There are no students in residence but distance teaching universities in this group are characterised by the use of multimedia and a more comprehensive linking between learning materials and student learning (Keegan, 1996). These are autonomous institutions with floating or adjunct faculty; no part-time/full-time or day-time/night-time dichotomies. Examples of such institutions include The Open University in the UK, Everyman's University in Israel, and the NOUN. At such universities, course writers and tutors are outsourced; learners are reached through a variety of media and methods. There may be additional elements of face-to-face approaches, thereby resulting in a blended or hybrid learning approach. However, because of its demanding capital-intensive nature, only a national government may want to embark on it (Omolewa \& Adekanmbi, 1994).

Independent study divisions of a conventional college or university might exist as Continuing Education and Extension Colleges where the responsibility of course development is on the institutions' faculty, albeit in form of paid overload. According to Keegan (1996), students study independently but such mode is not sufficient to acquire a full degree in many cases. Keegan (1996) replaced the consultation model (Keegan, 1990) with the consortium model, but his conceptualisation of the latter only focused on the institutional composition without specifying the didactic processes and provisions. Consortia "bring together universities or university departments, government agencies, business partners, radio, television and media production authorities for the purpose of enrolling students in distance education courses" (Keegan, 1996, p. 139). In any case, this model suggests that learners might carry out distinct activities in more than one institution, such as enrolment in one and didactic consultation in another. Students attend classes and participate in activities at nearby allocated institutions. In the last model, the integrated model, distance teaching is an extension of an already existing internal teaching programme coordinated by "a distinct form of distance education department within a conventional college or university" (Keegan, 1996, p. 140). The same faculty, which are "given a dual mandate" (p. 140) teach and assess sets of students in both the conventional and the distance education systems. In terms of cost, this model is the most manageable. Universities' centres for distance learning are examples of integrated or mixed institutions. Keegan's typology is not watertight and distance teaching systems have significantly evolved in the past three decades. The fact that 'the Australian integrated mode - New England model' now describes a common phenomenon, in Nigeria and other parts of the world, is an example of the evolution. Meanwhile, singlemode and dual-mode institutions broadly correspond to Keegan's autonomous distance teaching institutions and distance education departments of conventional institutions respectively. More specifically, NOUN is an example of distance teaching universities (Group 2) and OAU's CDL and IED are examples of the integrated model (Group 5).

\section{Methodology}

The study adopted a case study research design. This design was based on Yin (2003); Yin argued that case studies are favourable when investigating contemporary issues, and when behaviour cannot be controlled, 
as in the case of this study. The study population comprised administrators/facilitators and distance learning students at NOUN and OAU. The sample for the study comprised 38 participants (30 administrators/facilitators and 8 students) selected using a purposive sampling technique. Two students were selected from each of NOUN's Ikeja Study Centre (Lagos State) and Osogbo Study Centre (Osun State). These two centres were selected because they were accessible, and because the Ikeja centre was archetypical while the Osogbo centre was closer to Ile-Ife, the host of the second institution. Lagos being the economic nerve centre of Nigeria, the study centres there had the greater potential of drawing students from among people of varied backgrounds. Two students were selected from each of OAU's CDL (online programme) and IED (part-time programme). Furthermore, 15 administrators/facilitators were selected from each of the two institutions. For NOUN, the 15 administrators/facilitators included 8 from the Ikeja Study Centre and 7 from the Osogbo Study Centre. For OAU, the administrators/facilitators included 8 involved in IED programmes and 7 involved in CDL programmes.

Data were obtained through key informant questionnaires, key informant interviews, and desk research. From each of the institutions, 15 administrators/facilitators responded to the questionnaire, and 4 administrators/facilitators and 4 students were interviewed. These 8 interviewees from each institution were selected out of the total sample based on institution, subsystem and educational role, (see Table 1). This selection was made so as to enable comparisons at an institutional level. Collected data were analysed through tabular juxtaposition and phenomenological analysis techniques. The tabular juxtaposition technique provided a bird's-eye view of the comparative findings in the case institutions. The phenomenological analyses related to the perspectives of the individual and was qualitative analysis of narrative data with the goal to describe a lived experience of a phenomenon (Adebisi, 2018; Barrow, 2017). Table 1 summarizes the codes used to identify the 16 interviewees.

\section{Table 1}

\section{Codes for Interviews of Participants in the Study}

\begin{tabular}{|c|c|c|}
\hline $\mathrm{S} / \mathrm{N}$ & Interviewee & Code \\
\hline 1 & NOUN Lagos Study Centre student 1 & NOUN LSCS 1 \\
\hline 2 & NOUN Lagos Study Centre student 2 & NOUN LSCS 2 \\
\hline 3 & NOUN Osogbo Study Centre student 1 & NOUN OSCS 1 \\
\hline 4 & NOUN Osogbo Study Centre student 2 & NOUN OSCS 2 \\
\hline 5 & NOUN Lagos Study Centre administrator/facilitator 1 & NOUN LSCAF 1 \\
\hline 6 & NOUN Lagos Study Centre administrator/facilitator 2 & NOUN LSCAF 2 \\
\hline 7 & NOUN Osogbo Study Centre administrator/facilitator 1 & NOUN OSCAF 1 \\
\hline 8 & NOUN Osogbo Study Centre administrator/facilitator 2 & NOUN OSCAF 2 \\
\hline 9 & OAU Institute of Education student 1 & OAU IEDS 1 \\
\hline 10 & OAU Institute of Education student 2 & OAU IEDS 2 \\
\hline 11 & OAU Centre for Distance Learning student 1 & OAU CDLS 1 \\
\hline 12 & OAU Centre for Distance Learning student 2 & OAU CDLS 2 \\
\hline 13 & OAU Institute of Education administrator/facilitator 1 & OAU IEDAF 1 \\
\hline 14 & OAU Institute of Education administrator/facilitator 2 & OAU IEDAF 2 \\
\hline 15 & OAU Centre for Distance Learning administrator/facilitator 1 & OAU CDLAF 1 \\
\hline
\end{tabular}




\section{Results and Discussion}

Table 2 shows the operational structures (i.e., processes and facilities) identified at NOUN and OAU. Results showed that while NOUN as an open and flexible learning system relied on the use of connected distributed classes, OAU had two autonomous subsystems that provided distance education, namely IED (part-time) and CDL (online).

\section{Table 2}

Operational Structures of Distance Education at NOUN (Single Mode) and OAU (Dual Mode)

\begin{tabular}{|c|c|c|}
\hline Item & NOUN & OAU \\
\hline \multicolumn{3}{|l|}{ Where do admission screening, payment of fees, and course registration take place? } \\
\hline Via the Internet (online) & $\checkmark$ & $\checkmark$ \\
\hline Study Centre/Unit (for screening) & $\checkmark$ & $\checkmark$ \\
\hline Institution's headquarters & - & - \\
\hline \multicolumn{3}{|l|}{ What modes of admission are available in the distance education programmes? } \\
\hline O Level (Senior School Certificate Examination [SSCE]) & $\checkmark$ & - \\
\hline $\begin{array}{l}\text { Direct entry with National Diploma (ND), Nigeria Certificate in Education (NCE) } \\
\text { and other professional certificates }\end{array}$ & $\checkmark$ & $\checkmark$ \\
\hline Access/foundation/pre-degree programmes & $\checkmark$ & - \\
\hline \multicolumn{3}{|l|}{ Major instructional materials/resources used } \\
\hline Print media (hard and soft copies) & $\checkmark$ & $\checkmark$ \\
\hline Audio-visual materials (CD, DVD, VCD) & $\checkmark$ & - \\
\hline Materials programmed on mobile devices & - & $\checkmark$ (CDL only) \\
\hline Materials uploaded on the school's website & - & $\checkmark(\mathrm{CDL}$ only) \\
\hline \multicolumn{3}{|l|}{ On which platforms do facilitators have contact with students? } \\
\hline Online/virtual via e-mail, chat rooms, forums & $\checkmark$ & $\checkmark$ \\
\hline Online/virtual via teleconference & $\checkmark$ & - \\
\hline Virtual via radio and television & $\checkmark$ & - \\
\hline Face-to-face at the campus (weekends and holidays) & - & - \\
\hline Face-to-face at distributed classes/centres (weekends and holidays) & - & $\checkmark$ \\
\hline Face-to-face at distributed classes/centres (week days) & - & - \\
\hline Blended learning (physical and virtual/online meetings) & $\checkmark$ & $\checkmark$ (CDL only) \\
\hline As agreed upon by students and facilitators & - & - \\
\hline \multicolumn{3}{|l|}{ To what extent is it compulsory to attend scheduled contacts (classes)? } \\
\hline Compulsory (rules-based) & - & $\checkmark$ \\
\hline As facilitators decide & - & - \\
\hline As the centre coordinator decides & - & - \\
\hline As the coordinator and students agree & - & - \\
\hline Not compulsory & $\checkmark$ & - \\
\hline \multicolumn{3}{|l|}{ Where are examinations conducted? } \\
\hline Physical classroom & $\checkmark$ & $\checkmark$ \\
\hline
\end{tabular}


Online

Both physical and online

Flexible (students can choose where and when)

Partnership or affiliation with other units within the institution or with other institutions

Libraries/resource centres (public or private)

Other universities/colleges/polytechnics

Other unit(s) within the institution

Note. $\checkmark=$ Yes; $-=$ No.

\section{ICT and the Internet: Digitalised Processes}

The analysis showed that in both institutions, admission screening, payment of fees, course registration, and other similar processes were done via the Internet. This aligns with the observation by Abdel-Maksoud (2018) that virtualisation technology was increasingly becoming common in education due to its potential to reduce costs, boost efficiency, and overcome limited physical resources. The two institutions were similar with regards to where admission screening, payment of fees, and course registration took place. These processes were predominantly carried out online, also evidenced in the statement that "everything is online" (OAU CDLAF 1). This predominant deployment of online processes sets the tone for why any distance education student these days must be "ICT compliant" (NOUN OSCAF 1) and "ICT conscious" (OAU IEDAF 1). However, physical presence was sometimes required at the institutions' designated offices for such processes, especially for screening. It was often necessary that hard copies of supporting documents and printouts of applications, payments, and registrations be submitted to double-check online activities. Technical hitches occasionally made the NOUN students do more offline than necessary, especially when the electronic portal was down and this made the process "quite stressful" (NOUN LSCS 2).

\section{Modes of Admission}

Regarding admission, NOUN relied heavily on admitting students through the pre-degree programme (also called Access or Foundation Programme), O Level (SSCE or General Certificate in Education [GCE]) results and direct entry into year two. At OAU, students were admitted through SSCE combined with National Diploma (ND), National Certificate in Education (NCE), and Institute of Chartered Accountants of Nigeria (ICAN) for direct entry. Applicants were not expected to sit for Unified Tertiary Matriculation Examination (UTME) before admission into both universities, into 100 or 200 level as the case may be. "We don't need to collect any form from Joint Admissions and Matriculation Board (JAMB) again" (OAU IEDS 2). "You don't have to write JAMB exam [i.e., UTME] before you come in" (NOUN OSCAF 1). Modes of admission at NOUN and OAU were similar, though some aspects also differed. O Level results (with a minimum of five credit pass, including Mathematics and English in SSCE or GCE) were the usual basic requirement in both settings and candidates did not need to write the UTME. The SSCE/GCE could be from examinations conducted by the West Africa Examination Council or the National Examination Council. While applicants might gain admission into NOUN only on the merit of their O Level results, applicants interested in OAU usually had higher qualifications such as ND, NCE, or ICAN certificate depending on the courses they intended to pursue.

At OAU's CDL, candidates were admitted into the 100 level for Economics and Accounting programmes on the merits of their O Level results, but admission into any OAU IED programme was always through direct 
entry into 200 level (Part 2) with NCE or diploma in education. NOUN too required NCE/ND for direct entry admission. There was a prevailing alternative route to gain admission into NOUN, the Access or PreDegree Programme, for prospective undergraduates who had some deficiency in their O Level results. OAU did not have such pre-degree programme for prospective distance learners. It may be that the similarities in the admission processes are because they were both federal universities and/or subject to the same code of conduct and regulations of the NUC.

\section{Instructional Resources}

In the single-mode institution, major instructional resources were delivered via print media (both hard and soft copies), audio-visuals (CD, VCD, DVD), and uploads to the school's Website. The dual-mode institution used print media, materials programmed on mobile devices, and uploads to the school's Website. Materials programmed on mobile devices and uploads to the school's Website only applied in the case of OAU online distance learning; the part-time programmes still relied on print media. NOUN made its textbooks available as open access literature on the school Website where they were available for students and other scholars, but some students complained about late delivery and insufficiency of the materials. Print materials were central to academic activities but the study centre was meant to be a platform for various supports rather than for compulsory tutorials. OAU students were provided with print materials, and for CDL students only, audio/audio-visual materials programmed on mobile devices and materials uploaded to the school's Website. However, findings did not confirm Agyeman's (2007) report that NOUN already used videoconferencing for some course delivery. The use of radio and television was very limited and unpopular at NOUN, though these traditional media were supposed to be deployed for its operations.

Materials uploaded on CDL students' tablets and the centre's Website included video of studio-recorded lectures while OAU IED students relied on print media alone, except for those who personally made an effort to get learning resources through other platforms. This limitation is understandable considering that Nigerian society has been largely at the low extreme of the digital divide due to poor socio-economic, technological, and infrastructural developments. As Al-Alawneh (2013) argued, educational strategies should not be isolated from the context. Students and facilitators had issues with uploading or submitting assessments or uploading videos. One NOUN facilitator complained about the shortage of classes for tutorials. However, the two institutions achieved optimal results by combining available technology with the required pedagogy. In the words of two participant, "I think we have adequate technology to provide required distance learning in this Centre" (OAU CDLAF 1) and "if you are not ICT compliant you cannot meet up with the pace at which NOUN is growing” (NOUN OSCAF 1). According to Anderson and Simpson (2012), this ultimately means it was the combination of human, technological, and organisational resources that led to success.

\section{Blended Learning: Platforms and Patterns of Academic Contact}

In terms of contact platforms and patterns, blended learning modes (i.e., a combination of physical and online contacts) were observed in both institutions. Blended learning is a methodological approach for "simultaneous combination of learning, working and living, and vice versa" (Olatunji, Otefisan, \& Ajayi, 2017, p. 449). Ezekoka's (2015) study showed that three models of blended learning-face-to-face driver model, rotation model, and self-blend model-were practised at NOUN. At NOUN, students and facilitators interacted online via email, chat rooms, and discussion forums (e.g., iLearn and other online classrooms) 
as well as through face-to-face meetings at distributed classes and centres on weekdays. At OAU, only the CDL students enjoyed institution-arranged blended learning as they interacted among themselves and with facilitators via email, chat rooms, and online classrooms through the centre's learning management system (LMS) as well as physical contacts on selected weekends and holidays. A facilitator at the centre explained that compulsory physical contacts constituted $30 \%$ of the total contacts per semester in accordance with the NUC's no-full-online-education policy. Also, online students must attain at least $75 \%$ attendance. Pure online education has not yet been allowed in Nigeria.

At OAU, IED students were limited to face-to-face meetings at the school's campus on weekends (including Friday evenings), holidays, and during the long vacation period around July and August when primary and secondary schools were on break. The blended learning modes practised at the two institutions differed in that while NOUN students usually met face-to-face during weekdays, OAU students had such meetings during weekends and holidays. OAU students were older and most had work and family responsibilities; the result was a need for different schedules, compared with their NOUN counterparts. Attendance is compulsory for OAU students but not compulsory at NOUN. One student (NOUN OSCAF 1) stated that "for a two-credit unit course you have eight hour face-to-face contact with your facilitator." Whereas NOUN students are open learners, some younger individuals behave as if they are full-time students in the sense that they voluntarily attend tutorials and group discussions at the study centre as many days of the week as possible. Thus, some students opined that online tutorial activities were only for students who could not afford to come to study centres regularly.

\section{Continuous Assessment and Examination}

At NOUN, students had the option to write their examinations, worth about $60 \%$ of their total maximum obtainable mark, through both physical and online platforms. They also had some level of flexibility with regards to where and when they wrote examinations. However, at OAU, students in both subsystems were still restricted to writing their examinations in physical classrooms only. As OAU CDLAF 2 explained:

Quizzes and assignments are supposed to be online. Yes, but because we find it difficult to relate to the students on the LMS. Some use WhatsApp, some use e-mail. So, they submit an assignment by email and sometimes they [facilitators] give them an assignment on WhatsApp and say, "bring it during the face-to-face." Or during the face-to-face, they are given an assignment and they [facilitators] say, "bring it during the examination."

Participants from NOUN explained that students in 100-level and 200-level courses wrote online examinations, while students in subsequent levels wrote pen-and-paper examinations in designated physical classrooms. Moreover, a facilitator (NOUN LSCAF 2) added:

If I'm a student and I registered here in Lagos and an assignment is taking me to Abuja or any part of the country, I can get a letter from my study centre so that I can be allowed to sit for my examination in another study centre [all sic]. 


\section{Partnerships and Academic Staffing Patterns}

With regards to partnership or affiliation with other institutions or organisations, both institutions had some form of partnerships. As an open university, NOUN relied more on such partnerships because, for instance, its course writers, lecturers, and tutors were mostly outsourced from other universities, colleges, and polytechnics. Distance learners at OAU were taught by the university's lecturers, albeit under a different agreement. NOUN OSCAF 1 disclosed that "we have permanent staff, academic staff on board that take care of learners' needs. We have also facilitators from sister universities all over the country.”

Academic staffing patterns at the universities were understandably different; OAU tutors were full-time, in the sense that they were full-time employees of the university but working with its distance learning units on quasi part-time or contract basis, while NOUN had what Omolewa and Adekanmbi (1994) called floating faculty. OAU IEDAF 1 stated that "we make use of the lecturers that teach the same courses at the full-time and they teach the part-time. We don't employ associate lecturers from outside the university. We maintain the standard." For the online programme, as OAU CDLAF 1 explained:

There are two sets of facilitators. You have the instructors, who are the real lecturers teaching the students face-to-face... . Whereas, you have tutors who reside in the Centre for Distance Learning, providing a kind of support in terms of interaction with the students online.

However, we found that there was no longer a direct link or partnership between OAU's CDL and IED. The IED-CDL partnership was discontinued due to the need to provide affordable (i.e., less expensive) teacher education through distance education after the ban on outreach systems in the country. Table 3 summarises the details of operational structures and processes of distance learning at NOUN and OAU.

\section{Table 3}

Summary of Operational Structures at NOUN and OAU

\begin{tabular}{lll}
\hline Aspect & NOUN & OAU \\
\hline $\begin{array}{l}\text { Admission screening, } \\
\text { payment of fees, course } \\
\text { registration }\end{array}$ & $\begin{array}{l}\text { Online application, payment and } \\
\text { registration; physical screening; } \\
\text { admission every } \\
\text { semester }\end{array}$ & $\begin{array}{l}\text { Online application, payment and } \\
\text { registration; physical screening; } \\
\text { admission every session }\end{array}$ \\
$\begin{array}{l}\text { Modes of admission into } \\
\text { undergraduate }\end{array}$ & $\begin{array}{l}\text { Programme; O Level results; Direct } \\
\text { programmes }\end{array}$ & $\begin{array}{l}\text { Ontry with NCE/ND } \\
\text { NCE/ND/ICAN) }\end{array}$ \\
$\begin{array}{l}\text { Major instructional } \\
\text { materials/resources }\end{array}$ & $\begin{array}{l}\text { Print media (hard and soft copies); } \\
\text { audio-visual materials (CD, DVD, VCD); } \\
\text { materials uploaded to the school's } \\
\text { Website/portal }\end{array}$ & $\begin{array}{l}\text { Print Media (hard and soft copies); } \\
\text { materials programmed on mobile devices } \\
\text { (CDL only); materials uploaded on the } \\
\text { school's Website (CDL only) }\end{array}$
\end{tabular}


Platforms and patterns of contact
Online/virtual contact via email, chat rooms, phone, and social media; faceto-face meetings at distributed classes/centres on week days; blended learning (physical and virtual/online meetings)

Not compulsory

Both physical and online platforms; flexible (students can choose where and when)

\section{Staffing patterns}

Partnership or affiliation with other institutions or organisations
Full-time facilitators and part-time facilitators from other institutions Libraries/resource centres (public or private); other higher institutions; other unit(s) within the institution
Online/virtual contact via email, chat rooms, phone, and social media; face-toface meetings at institution's campus (weekends and holidays); blended learning mode (physical and virtual/online meetings; CDL only)

Compulsory

Physical classrooms

Full-time facilitators and quasi part-time facilitators from the university Libraries/resource centres (public or private); other higher institutions; other unit(s) within the institution

\section{Conclusion, Implications, and Recommendations}

The findings of this study do not provide generalisations about distance learning systems in Nigeria, but the following conclusions provide insights for a deeper understanding of the state of distance learning there. First, single- and dual-mode institutions are both similar and different in terms of their operational structures. Operational structures adopted in any mode of distance education should aim to create a learning process that is active, collaborative, and social. Second, personal, institutional, and situational barriers affect the availability and utilisation of facilities as well as study resources at both institutions. Availability and sufficiency of facilities, in turn, affects the adequacy of the operational structures in the institutions.

Although many differences are observable, NOUN and OAU seem to be evolving towards fulfilling their mandates, especially in the context of their inherent natures as a dedicated distance learning institution and a mixed distance learning institution, respectively. Centralisation of operations and facilities (i.e., Ifebound) characterises the dual-mode institution; part-time students want ICT to be deployed for blended learning. While the two universities are using blended learning approaches, OAU might have to incorporate this into its part-time studies in IED if it aims to keep pace with providing modern distance education. Meanwhile, any further upgrade of the OAU part-time subsystem would result in unaffordable financial cost implication for the students.

It is recommended that the deployment of ICT for various operational and instructional purposes be sustained in all forms of distance education but with an emphasis on usability, affordability, and ultimately to enhance learners' academic achievements. Dual-mode institutions, in particular, should devise means for utilising blended learning for all subsystems of distance education, including part-time students, 
especially to reduce cost and ease the stress of travelling. Both institutions must sustain what is working while they innovatively improve in other aspects. Indeed, virtualization technology has the potential to minimise costs, increase efficiency, and solve challenges of limited physical facilities. Promoting ICT-driven distance education, therefore, will help prospective learners access education irrespective of distance. 


\section{References}

Abdel-Maksoud, N. F. (2018). When virtual becomes better than real: Investigating the impact of a networking simulation on learning and motivation. International Journal of Education and Practice, 6(4), 253-270. https://eric.ed.gov/?id=Ej1210050

Abdulsalam, N., Condrasky, M., Bridges, W., \& Havice, P. (2017). The promise of andragogy and experimental learning to improve teaching of nutrition concepts to culinary arts students. Journal of Food Science Education, 16(2), 54-61. https://doi.org/10.1111/1541-4329.12107

Adanir, G. A., Ismailova, R., Omuraliev, A., \& Muhametjanova, G. (2020). Learners' perception of online exams: A comparative study in Turkey and Kyrgyzstan. International Review of Research in Open and Distance Learning, 21(3). https://doi.org/10.19173/irrodl.v21i3.4679

Adebisi, T. A. (2013). Attaining sustainable livelihood and democracy through vocational training and livelihood diversification. Journal of Nigerian National Council for Adult Education, 19(1), 6379. University Press PLC.

Adebisi, T. A. (2018). Training in the production of clan-bond trades in southwestern Nigeria: The nonformal and informal learning approaches. In A. Breedveld \& J. Jansen (Eds.), Education for life in Africa (pp. 266-285). African Studies Centre.

Adeleke, I., \& Adesina, O. (2018). An empirical comparison of the academic performance of students in the distance learning and traditional classroom environment. Social Science Asia, 4(1), 26-41. https://www.researchgate.net/publication/325300466

Agyeman, O. T. (2007). Survey of ICT and education in Africa: Nigeria country report. ICT for education in Nigeria. infoDev. https://www.infodev.org/infodev-files/resource/InfodevDocuments 422.pdf

Ahn, J., \& McEachin, A. (2017). Student enrollment patterns and achievement in Ohio's online charter schools. Educational Researcher, 46(1), 44-57. https://doi.org/10.3102/0013189X17692999

Ajadi, T. O., Salawu, I. O., \& Adeoye, F. A. (2008). E-learning and distance education in Nigeria. The Turkish Online Journal of Educational Technology, 7(4), 61-70. https://files.eric.ed.gov/fulltext/EJ1102939.pdf

Akande, O. J., \& Sofowora, O. A. (2011). Globalization information and communication technologies (ICTs) and open/distance learning in Nigeria: Trends, issues and solution. Turkish Online Journal of Distance Education, 12(3), 66-77. https://eric.ed.gov/?id=EJ965052

Akinwale, A., \& Onwuameze, D. (March 5, 2020). Nigeria overtakes South Africa as Africa's largest economy. This Day. https://allafrica.com/stories/202003050216.html 
Akter, N., \& Ali, A. (2016). Analysis of assignments' assessment for distance learners in single vs dual mode institutions. Bulletin of Education and Research, 38(2), 15-35. https://files.eric.ed.gov/fulltext/EJ1210304.pdf

Al-Alawneh, M. K. (2013). Examining e-learning barriers as perceived by faculty members of engineering colleges in the Jordanian universities. International Journal of Vocational and Technical Education, 5(4), 42-53. https://doi.org/10.5897/IJVTE2013.0121

Anderle, J. S. (2018). Procedural learning: A comparison of skills acquisition between an online environment and traditional classroom training (Order No. 10807895) [Doctoral dissertation, University of Wyoming]. ProQuest Dissertations and Theses Global.

Anderson, T., \& Cuttler, C. (2020). Open to open? An exploration of textbook preferences and strategies to offset textbook costs for online versus on-campus students. International Review of Research in Open and Distributed Learning, 21(1), 40-60. https://doi.org/10.19173/irrodl.v20i5.4141

Anderson, B., \& Simpson, M. (2012). History and heritage in distance education. Journal of Open, Flexible, and Distance Learning, 16(2), 1-10. https://files.eric.ed.gov/fulltext/EJ1080085.pdf

Baiyewu, L. (2017, June 6). NOUN graduates now eligible for NYSC, Law School. The Punch. https://punchng.com/noun-graduates-now-eligible-for-nysc-law-school/

Barrow, D. M. (2017). A phenomenological study of the lived experiences of parents of young children with autism receiving special education services (Doctoral dissertation). https://doi.org/10.15760/etd.5919

Biao, I. (2012). Open and distance learning: Achievements and challenges in a developing sub-educational sector in Africa. In P. B. Muyinda (Ed.), Distance education, (pp. 27-62). Intech Open.

Bušelić, M. (2012). Distance learning - concepts and contributions. Oeconomica Jadertina, 2(1), 23-34. https://doi.org/10.15291/oec.209

Commonwealth of Learning. (2001). Building capacity to deliver distance education in Nigeria's federal university system (Report prepared for the World Bank). https://docplayer.net/4801440Building-capacity-to-deliver-distance-education-in-nigeria-s-federal-university-system-reportprepared-for-the-world-bank.html

Duffy, T., Gilbert, I., Kennedy, D., \& Kwong, P. W (2002). Comparing distance education and conventional education: Observations from a comparative study of post-registration nurses. Research in Learning Technology, 1O(1). https://doi.org/10.3402/rlt.v10i1.11304

Ezekoka, G. K. (2015). Blended learning in National Open University of Nigeria (NOUN): Prospects and constraints. International Journal of Innovation and Research in Educational Sciences, 2(6), 457-461. 
https://www.ijires.org/administrator/components/com_jresearch/files/publications/IJIRES_45 7 Final.pdf

Federal Ministry of Education. (2000). Education today. Quarterly Journal of the Federal Ministry of Education, 8(3), 59-64.

Federal Republic of Nigeria. (2004). National policy on education (4th ed.). Nigerian Educational Research and Development Council. http://wbgfiles.worldbank.org/documents/hdn/ed/saber/supporting doc/AFR/Nigeria/TCH/N ational\%20Policy\%200n\%20Education.pdf

Federal Republic of Nigeria. (2013). National policy on education (6th ed.). Nigerian Educational Research and Development Council. https://educatetolead.files.wordpress.com/2016/02/national-education-policy2013.pdf

Gaskell, A., \& Mills, R. (2015). The quality and reputation of open, distance and e-learning: What are the challenges? Open Learning: The Journal of Open, Distance and e-Learning, 29(3), 190-205. https://doi.org/10.1080/02680513.2014.993603

Ikegulu, B., \& Oranusi, S. (2014). Distance and open learning in Nigeria: Progress, concerns and prospects. Journal of Education and Practice, 5(35), 167-171. https://core.ac.uk/download/pdf/234636688.pdf

Keegan, D. (1990). Foundations of distance education (2nd ed.) Routledge.

Keegan, D. (1996). Foundations of distance education (3rd ed.) Routledge.

López Soblechero, M. V., González Gaya, C., \& Hernández Ramírez, J. J. (2014). A comparative study of classroom and online distance modes of official vocational education and training. PLOS ONE 9(5), e96052. https://doi.org/10.1371/journal.pone.0096052

Naido, P. (March 5, 2020). Nigeria tops South Africa as the continent's biggest economy. Bloomberg. https://www.bloombergquint.com/business/nigeria-now-tops-south-africa-as-the-continent-sbiggest-economy

Obioha, M. F., \& Ndidi, U. B. (2011). Administrative problems of open distance education in Nigeria. A case study of National Open University of Nigeria. Journal of Educational and Social Research, 1(5), 89-97. https://www.richtmann.org/journal/index.php/jesr/article/view/11766/11372

Okonkwo, C. A. (2012). Assessment of challenges in developing self-instructional course materials at the National Open University of Nigeria. The International Review of Research in Open and Distributed Learning, 13(2), 221-231. https://doi.org/10.19173/irrodl.v13i2.930 
Olakulehin, F. K., \& Panda, S. K. (2011). Private cost of education: A comparative study of distance and campus-based university students in Nigeria. European Journal of Open, Distance and ELearning, (2), 1-12. https://files.eric.ed.gov/fulltext/EJ954910.pdf

Olatunji, T. I., Otefisan, M. A., \& Ajayi, F. O. (2017). Promoting adult education and lifelong learning in contemporary Nigeria through blended learning. Adult Education in Nigeria, 22(1), pp. 448-461. Ambik Press.

Omolewa, M., \& Adekanmbi, G. (Eds.). (1994). University initiatives in adult education. Ibadan University Press.

Onwe, O. J. (2013). Policies and practice of open and distance learning models in the sub-Saharan African countries: A literature survey. American International Journal of Contemporary Research, 3(8), 122-135.

https://citeseerx.ist.psu.edu/viewdoc/download?doi=10.1.1.1086.5371\&rep=rep1\&type=pdf

Oyeleke, O., \& Apena, T. T. (2018). Stakeholders' perception on some selected critical issues in open and distance education in Nigeria. Journal of Educational Foundations and Development, 7, 234243.

https://www.researchgate.net/publication/344197747 JOURNAL OF EDUCATIONAL FOUN DATIONS AND DEVELOPMENT 2018 VOLUME 07

Paul, J., \& Jefferson, F. (2019). A comparative analysis of student performance in an online vs. face-toface environmental science course from 2009 to 2016. Frontiers in Computer Science. 1(7). https://doi.org/10.3389/fcomp.2019.00007

Terwase, I. T., Abdul-Talib, A., \& Zengeni K. T., (2014). Nigeria, Africa’s largest economy: International business perspective. International Journal of Management Sciences, 3(7), 534-543. https://ideas.repec.org/a/rss/jnljms/v3izp8.html

Trindade, A. R., Carmo, H., \& Bidarra, J. (2000). Current developments and best practice in open and distance learning. International Review of Research in Open and Distributed Learning, 1(1), 125. https://doi.org/10.19173/irrodl.v1i1.7

Tucker, S. (2001). Distance education: Better, worse, or as good as traditional education? Online Journal of Distance Learning Administration, 4(4). https://www.westga.edu/ distance/ojdla/winter44/tucker44.html

Yin, R. (2003). Application of case study research. Sage.

Zormanová, L. (2016). The comparison of distance learning between the Czech Republic and other European countries. International Journal of Research in E-learning, 2(1), 88-103. https://www.researchgate.net/publication/335993205 The Comparison of Distance Learnin g Between the Czech Republic and Other European Countries 
Athabasca

University

(c) 